\title{
The role of $5-\mathrm{HT}_{3}$ and $5-\mathrm{HT}_{4}$ receptors in the adaptive mechanism of colonic transit following the parasympathetic denervation in rats
}

\author{
W. D. Tong ${ }^{1,2}$, Y. Kamiyama ${ }^{1}$, T. J. Ridolfi ${ }^{1}$, A. Zietlow ${ }^{1}$, J. Zheng ${ }^{1}$, L. Kosinski ${ }^{1}$, K. Ludwig $^{1}$, \\ and T. Takahashi ${ }^{1}$ \\ ${ }^{1}$ Department of Surgery, Medical College of Wisconsin and Zablocki VA Medical Center, \\ Milwaukee, Wisconsin, 53295, USA \\ 2 Department of General Surgery, Daping Hospital, Third Military Medical University, Chongqing, \\ 400042, China
}

\section{Abstract}

Background: Clinical studies show that disturbed colonic motility induced by extrinsic nerves damage is restored over time. We studied whether $5-\mathrm{HT}_{3}$ and $5 \mathrm{HT}_{4}$ receptors are involved in mediating the adaptive mechanisms following parasympathetic denervation.

Methods: Parasympathetic denervation of the entire colon was achieved by bilateral pelvic nerve transection and truncal vagotomy in rats. Colonic transit was measured by calculating the geometric center (GC) of ${ }^{51} \mathrm{Cr}$ distribution. Expression of $5-\mathrm{HT}_{3}$ and $5 \mathrm{HT}_{4}$ receptor mRNA was determined by real time RT-PCR.

Results: Parasympathetic denervation caused a significant delay in colonic transit $(\mathrm{GC}=4.36)$ at postoperative day (POD) 1, compared to sham operation $(\mathrm{GC}=6.31)$. Delayed transit was gradually restored by POD $7(\mathrm{GC}=5.99)$ after the denervation. Restored colonic transit was antagonized by the administration of 5- $\mathrm{HT}_{3}$ and $5 \mathrm{HT}_{4}$ receptors antagonists at $\mathrm{POD} 7.5-\mathrm{HT}_{3}$ and $5 \mathrm{HT}_{4}$ receptors mRNA expression were significantly increased in the mucosal/submucosal layer at POD 3 or POD 7, whereas no significant difference was observed in the longitudinal muscle layers adherent with the myenteric plexus (LMMP).

Conclusions: It is suggested that upregulation of 5- $\mathrm{HT}_{3}$ and $5-\mathrm{HT}_{4}$ receptors expression in the mucosal/submucosal layer is involved to restore the delayed transit after the parasympathetic denervation in rats.

\section{Keywords}

5- $\mathrm{HT}_{3}$ receptor; 5- $\mathrm{HT}_{4}$ receptor; colon; parasympathetic; denervation

Correspondence: Toku Takahashi, MD, PhD Zablocki VA Medical Center 5000 West National Avenue Milwaukee, WI 53295 Phone: 414-384-2000 (ext. 41472) Fax 414-382-5374 ttakahashi@ mcw.edu.

Publisher's Disclaimer: This is a PDF file of an unedited manuscript that has been accepted for publication. As a service to our customers we are providing this early version of the manuscript. The manuscript will undergo copyediting, typesetting, and review of the resulting proof before it is published in its final citable form. Please note that during the production process errors may be discovered which could affect the content, and all legal disclaimers that apply to the journal pertain.

No conflicts of interest exist 


\section{Introduction}

The autonomic nervous system plays an important role in regulating colorectal motility. The colon is supplied by dual parasympathetic innervation, namely the vagus and pelvic nerves 1-3. Injury to these nerves from surgical and obstetrical trauma has long been cited as a cause for abnormal colorectal motility in humans ${ }^{4-6}$. The pelvic plexus is presumably susceptible during hysterectomy, especially those nerves lying in the base of the broad ligament that are ligated with the uterine arteries ${ }^{7-9}$. Similar nerve injury can occur, possibly by mechanical stretching of nerves during prolonged childbirth ${ }^{4,10}$. Transection of pelvic nerves has been shown to decrease contractile complexes in the colon of dogs ${ }^{11}$. In humans, defecation is impeded after surgical sectioning of the pelvic nerves ${ }^{12,13}$. However, the effect of extrinsic nerve injury on colorectal motility has not been fully investigated.

While 5-HT acts as a neurotransmitter of the central and enteric nervous system, the majority of 5-HT is stored in enterochromaffin (EC) cells in the gastrointestinal (GI) tract. EC cells act as sensory transducers that activate the mucosal processes of both intrinsic and extrinsic primary afferent neurons through their release of 5-HT acting on multiple distinct 5-HT receptors ${ }^{14-16}$. To date, fourteen 5-HT receptors have been characterized and divided into seven classes ${ }^{17}$. Among them, $5-\mathrm{HT}_{3}$ and $5-\mathrm{HT}_{4}$ receptors appear to play significant roles to regulate colonic peristalsis.

In vitro studies have shown that the stimulation of intrinsic primary afferent neurons (IPANs) activates excitatory motor neurotransmitters including acetylcholine (ACh) and substance $\mathrm{P}$ (SP) as well as inhibitory motor neurotransmitters such as nitric oxide (NO) and vasointestinal polypeptide (VIP) within the myenteric plexus. This leads to an orad contraction of the smooth muscle and coordinated aboral relaxation, respectively, generating a pressure gradient and peristalsis ${ }^{18}$. 5 -HT acts via receptors located on the sensory calcitonin gene-related peptide (CGRP) neurons. CGRP release induced by mucosal stimulation is abolished by $5-\mathrm{HT}_{4}$ antagonists in rats and humans and by a combination of 5$\mathrm{HT}_{3}$ and $5-\mathrm{HT}_{4}$ antagonists in guinea pigs ${ }^{18}$. Thus, 5 -HT-induced peristalsis is mediated exclusively via $5-\mathrm{HT}_{4}$ receptors in human and rat colon, whereas $5-\mathrm{HT}$ acts via both $5-\mathrm{HT}_{3}$ and $5-\mathrm{HT}_{4}$ receptors in guinea pig in vitro ${ }^{18}$.

In addition, 5- $\mathrm{HT}_{3}$ receptors of extrinsic origin are involved in the regulation of colonic peristalsis in rats in vivo ${ }^{19}$. Accelerated colonic transit and diarrhea induced by stress are inhibited by $5-\mathrm{HT}_{3}$ receptor antagonists in conscious rats ${ }^{20} .5-\mathrm{HT}_{3}$ receptors are synthesized at the nodose ganglia (NG) of vagal afferent nerves ${ }^{21}$ and the dorsal root ganglia (DRG) of pelvic nerve afferents ${ }^{22,23}$, as well as IPANs ${ }^{24} .5-\mathrm{HT}_{3}$ receptors are then retrogradely transported to the nerve terminals of vagal and pelvic afferents where 5-HT can stimulate them as has been demonstrated ${ }^{16,25,26}$. Intraluminal infusion of 5-HT increases vagal afferent discharges in the same NG neurons that are activated by luminal stimuli ${ }^{26}$. Thus, $5-\mathrm{HT}_{3}$ receptors are both of intrinsic and extrinsic origins in rats ${ }^{21}$. In contrast, there have been no reports that $5-\mathrm{HT}_{4}$ receptors are synthesized in the NG or DRG.

We have previously shown that 5-HT released from EC cells stimulates $5-\mathrm{HT}_{3}$ receptors located on the vagal sensory fibers. The sensory information is transferred through the brain stem (nucleus tractus solitarius and dorsal motor nucleus of vagi), to the vagal efferent and stimulates the release of acetylcholine from the colonic myenteric plexus, resulting in acceleration of colonic transit 27,28 . Thus, $5-\mathrm{HT}_{3}$ receptors of extrinsic origin mediate colonic peristalsis via extrinsic neural pathways in conscious rats in vivo 27,28 .

Clinically, it has been demonstrated that adaptation occurs to restore impaired colonic motility after extrinsic denervation ${ }^{29}$. However, the mechanism by which this adaptation 
process takes place remains unclear. It also remains unknown whether the expression of 5$\mathrm{HT}_{3}$ and $5-\mathrm{HT}_{4}$ receptors of the colonic wall is altered in response to extrinsic nerve injury.

The aims of this study were to investigate the effects of parasympathetic denervation on colonic transit and elucidate the adaptation mechanisms responsible for its restoration over time. We tested the hypothesis that $5-\mathrm{HT}_{3}$ and $5-\mathrm{HT}_{4}$ receptors of intrinsic origin are upregulated in order to compensate for the loss of $5-\mathrm{HT}_{3}$ receptors of extrinsic origin after parasympathetic denervation.

\section{Materials and Methods}

\section{Animals}

Animals were maintained and handled in accordance with policies of the Animal Care and Use Committee of Clement J. Zablocki VA Medical Center (Milwaukee, WI). Male Sprague-Dawley rats were obtained from Charles River Laboratories (Hollister, CA; initial weight 225-250 g) and maintained in the animal care facility at the Clement J. Zablocki VAMC, Milwaukee WI. The animals were housed in a controlled environment $\left(21 \pm 1^{\circ} \mathrm{C}\right.$, $50-70 \%$ humidity, 12 hour light dark cycle) and given free access to tap water and standard rat chow (LabDiet 5001-Rodent Diet, PMI International). All rats were housed at standard conditions for at least 7 days prior to any experimentation. Rats were individually caged following each procedure.

\section{Colonic transit study after the parasympathetic denervation}

Under the isoflurane (2\%) anesthesia, a midline abdominal incision was made and the stomach pulled in the caudal direction to expose the distal part of esophagus in male Sprague-Dawley rats. As previously reported ${ }^{30}$, bilateral diaphragmatic truncal vagotomy was performed under a dissecting microscope. Pelvic ganglia were identified in each animal using gentle manipulation with cotton tipped applicators, as previously reported ${ }^{31}$. Bilateral pelvic nerves were sectioned where it emerged from sacral root. Sham operated rats served as controls.

Sixty two male rats underwent placement of a silicone tube into the proximal colon, as previously reported ${ }^{28,31}$. A silicone tube ( $I D=1 / 32 \mathrm{in}, \mathrm{OD}=3 / 32 \mathrm{in}$ ) was placed within the proximal colon through a colotomy made in the cecum. The catheter was secured to the cecum using 3-0 silk in a purse-string fashion. The proximal portion of the tube was brought through the left abdominal wall and tunneled beneath the skin to the posterior neck and fixed to the skin. To prevent urine retention, the bladder was manually decompressed twice daily in rats who underwent pelvic nerve transaction, as the pelvic nerve regulates bladder emptying. Carprofen ( $5 \mathrm{mg} / \mathrm{kg}$, once a day for 2 days) was be given subcutaneously after the surgery for analgesia.

To evaluate colonic transit after nerve transection, $0.2 \mathrm{ml}$ of ${ }^{51} \mathrm{Cr}(2.5 \mu \mathrm{Ci} / \mathrm{ml}$; Perkin Elmer, Waltham, MA) was injected and flushed with $0.2 \mathrm{ml}$ normal saline via the catheter into the proximal colon on postoperative days (POD) 1,3 , and 7 . Three hours after the administration of ${ }^{51} \mathrm{Cr}$, the entire colon was removed and divided into 10 equal segments. Feces excreted within the 3 hour period were collected and referred to as segment 11 . The radioactivity of each segment was ascertained by use of a gamma counter (Perkin Elmer-2470, Waltham, MA).

To determine the involvement of $5-\mathrm{HT}_{3}$ and $5-\mathrm{HT}_{4}$ receptors in mediating colonic transit following the parasympathetic denervation, ondansetron $(1 \mathrm{mg} / \mathrm{kg})$ or GR125,487 $(1 \mathrm{mg} / \mathrm{kg})$ were administrated subcutaneously 15 min prior to ${ }^{51} \mathrm{Cr}$ injection at POD 7. The dose of ondansetron $(1 \mathrm{mg} / \mathrm{kg})$ and GR125,487 (1 mg/kg) was selected based our previous study ${ }^{32}$. 
The distribution of radiochromium was quantified as a geometric center (GC), as previously reported 28, 31 .

\section{Real time RT-PCR}

At POD 1, 3 and 7, rats were euthanized by isoflurane (5\%). The entire colon was excised rapidly and placed into ice-cold DNase and RNase free water (W4502, Sigma, MO). A $2 \mathrm{~cm}$ segment of proximal colon, mid colon, and distal colon were harvested and opened along the mesenteric border, the contents were flushed out with RNase-free water. 5- $\mathrm{HT}_{3}$ and 5-HT receptors mRNA are detected in the cell bodies of the myenteric plexus and submucosal plexus. Under a dissecting microscope, each sample was separated as mucosal/submucosal layer and longitudinal muscle layers adherent with the myenteric plexus (LMMP). The tissues then were homogenized in Trizol (Invitrogen, Carsvad, CA) and immediately stored at $-80^{\circ} \mathrm{C}$.

The total RNA isolation and real time Reverse Transcription-PCR (RT-PCR) have been previously described in detail ${ }^{33}$. Briefly, total RNA was extracted from tissue using Trizol (Invitrogen, Carsbad, CA) according to manufacturer's instructions. Potential trace DNA contamination was removed by DNase digestion (Promega, Madison, WI). Complementary DNA (cDNA) was synthesized from $3 \mu \mathrm{g}$ total RNA using Superscript III reverse transcriptase (Invitrogen, Carsbad, CA). The resulting cDNA was used as template for realtime PCR using LightCycler 480 (Roche, Diagnostics, Mannheim, Germany) with SYBR Premix Ex Taq ${ }^{\text {TM }}$ (\#RR041A, Takara Bio, Madison, WI, USA) according to manufacturer's protocol. Standard curves were performed for each gene by serial dilutions (Easy dilution, Takara Bio, Madison, WI) of the corresponding cDNA. Primer (Integrated DNA Technologies, Coralville, IA, USA) sequences were: $\beta$-actin (106 bp) as previously reported ${ }^{34}$, forward primer: 5'- TTGAGCCCAGAGCACCAGAAA-3', reverse primer: 5'GGGTCATCTTTTCACGGTTGG-3'; 5-HT 3 receptor (67 bp), as previously reported ${ }^{35}$, forward primer 5'-TGCATACCATCCAGGACATCA-3', reverse primer: 5'CTCTTGTCCGAC CTCACTTCTTC-3'; 5-HT 4 R (212 bp, designed with Primer 3 software, NCBI), forward primer: 5'-GAGACCAAAGCAGCCA AGAC-3', reverse primer: 5'AGGAAGGCACGTCTGAAAG A-3'. Amplifications were performed in a final volume of $20 \mu \mathrm{l}$ of a commercial reaction mixture according to the manufacturer's instructions. The primers for the amplification of cDNA encoding $\beta$-actin, $5-\mathrm{HT}_{3}$ receptor, and $5-\mathrm{HT}_{4}$ receptor were used at a final concentration of $0.4 \mu \mathrm{M}$. Thermal cycling parameters were 10 sec at $95^{\circ} \mathrm{C}$, followed by 40 cycles for $10 \mathrm{sec}$ at $95^{\circ} \mathrm{C}, 15 \mathrm{sec}$ at $60^{\circ} \mathrm{C}$ and $20 \mathrm{sec}$ at $72^{\circ} \mathrm{C}$. Melting point analysis was undertaken on each set of reactions to determine that only a single product was produced. Amplicon sizes were confirmed by $2 \%$ agarose gel electrophoresis. Each sample was analyzed in triplicate and to ensure measurements form different PCR runs were cross-comparable, one particular sample from each group were used as reference (or "calibrator") for each PCR run. Quantification of 5- $\mathrm{HT}_{3}$ and 5-HT 4 receptors mRNA expression was performed relative to housekeeping gene (b-actin) measured in simultaneous runs of the same sample cDNA.

\section{Chemicals}

Ondansetron was purchased from Hospira (Lake Forest, IL) and GR125,487 sulfamate was purchased from Tocris (Ellisville, MO).

\section{Statistical analysis}

All data were expressed as means \pm SEM (standard error of mean). Statistical analysis was carried out with GraphPad Prism 5.0 software (San Diego, CA). Effect of 5--HT 3 and 5-HT 4 antagonists on colonic transit at POD7 was analyzed by one-way ANOVA followed by the 
post hoc Bonferroni test. All other data were analyzed by two-way ANOVA followed by the post hoc Bonferroni test. Statistical significance was defined as $P<0.05$.

\section{Results \\ Colonic transit after the parasympathetic denervation}

Postoperative ileus is transient bowel dysmotility following abdominal surgery. We have previously shown that colonic transit is delayed $3 \mathrm{hrs}$ after abdominal surgery (intestinal manipulation) and that delayed colonic transit is partially restored $27 \mathrm{hrs}$ after intestinal manipulation in rats ${ }^{36}$. In previous unpublished work we have found that at POD 5 rats undergoing placement of a colonic catheter without further surgical manipulation have a GC measuring $7.55 \pm 0.54(n=6)$. Our current study demonstrates that delayed colonic transit observed at POD 1was augmented by POD 3 and remained stable at POD 7 in sham operated rats $(\mathrm{n}=6)$, suggesting that postoperative ileus is resolved within 3 days (Fig. 1).

After parasympathetic denervation, a significant delay in colonic transit was observed at POD 1 and POD 3. The animals with parasympathetic denervation demonstrated delay in colonic transit with a GC of $4.36 \pm 0.64(\mathrm{n}=6, \mathrm{P}<0.05)$ at $\mathrm{POD} 1$ and $5.19 \pm 0.49(\mathrm{n}=8, \mathrm{P}<0.05)$ at POD 3, compared to that of the sham group [POD 1: 6.31 $\pm 0.62(n=8)$; POD 3: 7.63 \pm 0.21 $(\mathrm{n}=7)]$. The delayed colonic transit induced by the denervation was significantly accelerated at POD $7(\mathrm{GC}=5.99 \pm 0.58, \mathrm{n}=8, \mathrm{P}>0.05)$, compared to POD 1 (Fig. 1). These observations indicate that the delayed colonic transit induced by parasympathetic nerve damage can be restored over time in rats.

\section{Effects of 5-HT 3 and $5-\mathrm{HT}_{4}$ receptor antagonists on colonic transit after parasympathetic denervation}

On POD 7 following parasympathetic nerve transection, colonic transit was partially restored. The restored colonic transit was significantly antagonized by ondansetron $(1 \mathrm{mg} /$ $\mathrm{kg}$, sc) $(\mathrm{GC}=4.16 \pm 0.3, \mathrm{n}=6, \mathrm{P}<0.01)$, compared to that of saline-injected rats $(\mathrm{GC}=6.32 \pm 0.42, \mathrm{n}=6)$. The restored colonic transit was also significantly antagonized by GR125,487 (1 mg/kg, sc) $(\mathrm{GC}=5.65 \pm 0.23, \mathrm{n}=6, \mathrm{P}<0.05)$ (Fig. 2).

\section{Expression of 5- $\mathrm{HT}_{3}$ and $5-\mathrm{HT}_{4}$ receptor mRNA in mucosal/submucosal layer following the parasympathetic denervation}

No significant difference was observed at POD 1 in both $5-\mathrm{HT}_{3}$ and $5-\mathrm{HT}_{4}$ receptors mRNA expression. At POD 3, 5- $\mathrm{HT}_{3}$ receptor mRNA expression was significantly increased from the proximal to distal colon when compared to the sham group (Fig. 3A). Upregulated 5$\mathrm{HT}_{3}$ receptor mRNA expression was no longer observed at POD 7 (Fig. 3A).

Interestingly, at $\mathrm{POD} 3$, the significantly increased $5-\mathrm{HT}_{4}$ receptor mRNA expression was revealed only in the distal colon (Fig. 3B), while the increase of proximal colon and mid colon achieved significance on POD 7, compared to sham group (Fig. 3B).

\section{Expression of $5-\mathrm{HT}_{3}$ and $5-\mathrm{HT}_{4}$ receptor mRNA in the longitudinal muscle layer adherent with myenteric plexus (LMMP) following parasympathetic denervation.}

$5-\mathrm{HT}_{3}$ and $5-\mathrm{HT}_{4}$ receptors are also expressed in the myenteric plexus of the rat colon ${ }^{21,37}$. At POD 1, 3 and 7, there were no significant changes observed in mRNA expression of 5$\mathrm{HT}_{3}$ and $5-\mathrm{HT}_{4}$ receptors of the entire colon, compared to that of sham-operated rats (Fig. $4)$. 


\section{Discussion}

Extrinsic nerve injury has long been cited as a potential cause for several colorectal motility disorders 4, 7, 38, 39. Childbirth has also been associated with slow transit constipation with a putative mechanism of pelvic nerve crush injury following prolonged delivery 4,5 . It has been demonstrated that colonic transit is delayed in patients with paraplegia secondary to injury to parasympathetic outflow tracts ${ }^{40}$. Canine studies have shown a long lasting decrease in contractile complexes of colon following extrinsic denervation ${ }^{11}$.

We have previously showed that transection of pelvic nerves leads to a dramatic decrease in rectal motility whereas transection of hypogastric nerves causes an increase in rectal motility 31. Our recent study demonstrated that there is a pattern of dual innervation by parasympathetic fibers from both the vagus and pelvic nerves in the mid and distal colon in rats ${ }^{3}$. Therefore, in the current study, we chose parasympathetic denervation by bilateral truncal vagotomy plus pelvic nerve transection.

At POD 1 and POD 3 after parasympathetic denervation, colonic transit was significantly delayed. With time, the delayed colonic transit trended toward increasing GC. At POD 7, the colonic transit was significantly accelerated, compared to that of POD 1 . The adaptive changes have also been described clinically after colorectal operation, especially during the first year ${ }^{41,} 42$. In a prospective study of total mesorectal excision for rectal carcinoma, anorectal function after rectal surgery with or without radiotherapy is greatly hampered. However, the abnormalities partially recovered by 12 months postoperatively, indicating the motility of colon and rectum adapt over time ${ }^{41}$. In a vagotomized patient, no significant spontaneous contractions of the transverse colon were observed for 18 days after vagotomy. Then, the colonic contractions began to return slowly and almost reached preoperative levels 6 weeks after the operation ${ }^{29}$. In dogs, recovery of colonic motility after autonomic denervation occurs within several months ${ }^{11}$. However, the mechanism by which this adaptation process takes place remains unclear.

One possible compensatory or adaptive mechanism is the modulation of 5-HT receptors within the intrinsic nervous system of the colonic wall. The coordinated movement of bowel is dependent on 5-HT-mediated regulation of smooth muscle tone, peristalsis, mucosal secretion, and visceral perception 43,44 via intrinsic and/or extrinsic afferent neurons 45,46 . More than $90 \%$ of total body 5-HT is synthesized, stored and released by intestinal EC cells 47,48 . In response to chemical or mechanical luminal stimulation, 5-HT is released from EC cells into the lamina propria acting on distinct 5-HT receptors (mainly 5- $\mathrm{HT}_{3}$ and 5- $\mathrm{HT}_{4}$ receptors) at extrinsic and intrinsic primary afferent neurons $43,45,46,49$. An In vitro study showed that the peristaltic reflex was antagonized by the mucosal application of $5-\mathrm{HT}_{3}$ and $5-\mathrm{HT}_{4}$ receptor antagonists in the guinea pig colon ${ }^{18}$.

To test the hypothesis that $5-\mathrm{HT}_{3}$ and $5-\mathrm{HT}_{4}$ receptors are involved in the adaptive mechanism following the parasympathetic denervation, we administered $5-\mathrm{HT}_{3}$ and $5-\mathrm{HT}_{4}$ receptor antagonists at POD 7 and measured colonic transit. The restored colonic transit was significantly attenuated by $5-\mathrm{HT}_{3}$ or $5-\mathrm{HT}_{4}$ receptors antagonists. This suggests that $5-\mathrm{HT}_{3}$ and $5-\mathrm{HT}_{4}$ receptors of intrinsic origin may play a role in mediating colonic peristalsis following the extrinsic denervation.

To determine whether 5- $\mathrm{HT}_{3}$ and $5-\mathrm{HT}_{4}$ receptor mRNA expression is upregulated following parasympathetic denervation, quantitative real time RT-PCR was employed to detect the change in mRNA expression from POD 1 to POD 7 of the mucosal/submucosal layer as well as LMMP. In the mucosal/submucosal layer, 5- $\mathrm{HT}_{3}$ receptor mRNA expression was significantly increased in the proximal, mid and distal colon at POD 3 . The upregulated 5- $\mathrm{HT}_{3}$ receptor mRNA expression was no longer observed at POD 7. 
5- $\mathrm{HT}_{3}$ receptors of extrinsic origin initiate peristalsis via extrinsic neural pathways in rats in vivo 27,28 . It has been shown that fibers immunoreactive for $5-\mathrm{HT}_{3}$ receptors in the duodenal mucosa are markedly reduced by subdiaphragmatic vagotomy or chemical denervation of vagal afferents in rats ${ }^{21}$. Following damage to vagus and pelvic nerves, 5$\mathrm{HT}_{3}$ receptors synthesized at the NG and DRG of the parasympathetic afferent cannot be transported to the nerve terminals of the lamina propria. It is likely that $5-\mathrm{HT}_{3}$ receptor expression may be upregulated in the mucosal/submucosal layer, to compensate the loss of $5-\mathrm{HT}_{3}$ receptors of extrinsic origin following the denervation.

We found that only the distal colon displayed significantly increased $5-\mathrm{HT}_{4}$ receptor mRNA expression at POD 3. However, at POD 7, both the proximal colon and mid colon showed significant increase of 5- $\mathrm{HT}_{4}$ receptor mRNA expression. It seems that upregulation of 5$\mathrm{HT}_{4}$ receptor mRNA expression in response to the parasympathetic denervation occurred later than that of 5- $\mathrm{HT}_{3}$ receptor. The mechanism of delayed development of 5- $\mathrm{HT}_{4}$ receptor mRNA expression remains to be studied. One possible explanation is due to the difference of their distribution. In contrast to $5-\mathrm{HT}_{3}$ receptors, $5-\mathrm{HT}_{4}$ receptors are exclusively located on the terminals of IPANs in both of the submucosal and myenteric plexus ${ }^{50,51}$. Although there is an early change in $5-\mathrm{HT}_{3}$ receptor expression, extrinsic denervation may cause long term effects via $5-\mathrm{HT}_{4}$ receptor expression within the enteric nervous system. It still remains unknown whether upregulated $5-\mathrm{HT}_{3}$ and $5-\mathrm{HT}_{4}$ receptors act differently in the modulation of restored colonic transit after the parasympathetic denervation.

A 5- $\mathrm{HT}_{4}$ agonist (mosapride) enhances intrinsic rectorectal and rectoanal reflexes after the removal of extrinsic nerves in guinea pigs in vivo ${ }^{52}$. This suggests that extrinsic denervation may increase the sensitivity to $5-\mathrm{HT}_{4}$ receptors of the guinea pig rectum. However, it still remains unclear whether a $5-\mathrm{HT}_{4}$ receptor agonist acts on the mucosal/submuosal or muscular layers following extrinsic denervation.

Whereas significant upregulation of 5- $\mathrm{HT}_{3}$ and $5-\mathrm{HT}_{4}$ receptor mRNA expression was observed in the mucosal/submucosal layer, neither $5-\mathrm{HT}_{3}$ nor $5-\mathrm{HT}_{4}$ receptors mRNA expression was significantly altered in the LMMP from POD 1 to POD 7. This suggests that $5-\mathrm{HT}_{3}$ and $5-\mathrm{HT}_{4}$ receptors of the myenteric plexus may not play a major role in restoring colonic transit after the parasympathetic denervation in rats.

In conclusion, we showed that colonic transit was significantly delayed in the early phase of parasympathetic denervation and that the delayed transit was recovered in a week after the denervation in rats. Upregulated $5-\mathrm{HT}_{3}$ and $5-\mathrm{HT}_{4}$ mRNA receptors expression in the mucosal/submucosal layer may be involved in the mechanism of restored transit after the denervation. The related study of protein expression of $5-\mathrm{HT}_{3}$ and $5-\mathrm{HT}_{4}$ receptors is now ongoing in our laboratory.

Changes in serotonin signaling have been demonstrated in inflammatory bowel disease, irritable bowel syndrome, post-infectious irritable bowel syndrome and idiopathic constipation ${ }^{53}$. We have demonstrated, for the first time, that extrinsic denervation upregulates the expression of 5-HT receptors in the rat colon.

\section{Acknowledgments}

This study was supported in part by the National Institute of Diabetes and Digestive and Kidney Diseases (RO1 DK62768, T.T.). 


\title{
Abbreviations
}

\author{
EC enterochromaffin \\ IPANs intrinsic primary afferent neurons \\ POD postoperative day \\ GC geometric center \\ LMMP longitudinal muscle layers adherent with the myenteric plexus
}

\section{References}

1. Langley JN, Anderson HK. On the Innervation of the Pelvic and Adjoining Viscera: Part I. The Lower Portion of the Intestine. J Physiol. 1895; 18:67-105.

2. Langley JN, Anderson HK. The Innervation of the Pelvic and adjoining Viscera: Part VI. Histological and Physiological Observations upon the Effects of Section of the Sacral Nerves. J Physiol. 1896; 19:372-84.

3. Tong WD, Ridolfi TJ, Kosinski L, Ludwig KA, Takahashi T. Effects of autonomic nerve stimulation on colorectal motility in rats. Neurogastroenterol Motil. 2010 in press.

4. Knowles CH, Scott SM, Lunniss PJ. Slow transit constipation: a disorder of pelvic autonomic nerves? Dig Dis Sci. 2001; 46:389-401. [PubMed: 11281190]

5. MacDonald A, Baxter JN, Bessent RG, Gray HW, Finlay IG. Gastric emptying in patients with constipation following childbirth and due to idiopathic slow transit. Br J Surg. 1997; 84:1141-3. [PubMed: 9278663]

6. MacDonald A, Baxter JN, Finlay IG. Idiopathic slow-transit constipation. Br J Surg. 1993; 80:110711. [PubMed: 8402105]

7. Possover M, Schneider A. Slow-transit constipation after radical hysterectomy type III. Surg Endosc. 2002; 16:847-50. [PubMed: 11997835]

8. Roe AM, Bartolo DC, Mortensen NJ. Slow transit constipation. Comparison between patients with or without previous hysterectomy. Dig Dis Sci. 1988; 33:1159-63. [PubMed: 3409802]

9. Vierhout ME, Schreuder HW, Veen HF. Severe slow-transit constipation following radical hysterectomy. Gynecol Oncol. 1993; 51:401-3. [PubMed: 8112652]

10. Handa VL, Harris TA, Ostergard DR. Protecting the pelvic floor: obstetric management to prevent incontinence and pelvic organ prolapse. Obstet Gynecol. 1996; 88:470-8. [PubMed: 8752261]

11. Ishikawa M, Mibu R, Iwamoto T, Konomi H, Oohata Y, Tanaka M. Change in colonic motility after extrinsic autonomic denervation in dogs. Dig Dis Sci. 1997; 42:1950-6. [PubMed: 9331160]

12. Devroede G, Lamarche J. Functional importance of extrinsic parasympathetic innervation to the distal colon and rectum in man. Gastroenterology. 1974; 66:273-80. [PubMed: 4810918]

13. Gunterberg B, Kewenter J, Petersen I, Stener B. Anorectal function after major resections of the sacrum with bilateral or unilateral sacrifice of sacral nerves. Br J Surg. 1976; 63:546-54. [PubMed: 953450]

14. Grider JR, Kuemmerle JF, Jin JG. 5-HT released by mucosal stimuli initiates peristalsis by activating 5-HT4/5-HT1p receptors on sensory CGRP neurons. Am J Physiol. 1996; 270:G77882. [PubMed: 8967488]

15. Bertrand PP, Kunze WA, Furness JB, Bornstein JC. The terminals of myenteric intrinsic primary afferent neurons of the guinea-pig ileum are excited by 5-hydroxytryptamine acting at 5hydroxytryptamine-3 receptors. Neuroscience. 2000; 101:459-69. [PubMed: 11074168]

16. Gershon MD. Nerves, reflexes, and the enteric nervous system: pathogenesis of the irritable bowel syndrome. J Clin Gastroenterol. 2005; 39:S184-93. [PubMed: 15798484]

17. Hoyer D, Martin G. 5-HT receptor classification and nomenclature: towards a harmonization with the human genome. Neuropharmacology. 1997; 36:419-28. [PubMed: 9225265] 
18. Grider JR, Foxx-Orenstein AE, Jin JG. 5-Hydroxytryptamine4 receptor agonists initiate the peristaltic reflex in human, rat, and guinea pig intestine. Gastroenterology. 1998; 115:370-80. [PubMed: 9679042]

19. Gershon MD. Review article: roles played by 5-hydroxytryptamine in the physiology of the bowel. Aliment Pharmacol Ther. 1999; 13(Suppl 2):15-30. [PubMed: 10429737]

20. Miyata K, Ito H, Fukudo S. Involvement of the 5-HT3 receptor in CRH-induce defecation in rats. Am J Physiol. 1998; 274:G827-31. [PubMed: 9612262]

21. Glatzle J, Sternini C, Robin C, Zittel TT, Wong H, Reeve JR Jr. Raybould HE. Expression of 5HT3 receptors in the rat gastrointestinal tract. Gastroenterology. 2002; 123:217-26. [PubMed: 12105850]

22. Hicks GA, Coldwell JR, Schindler M, Ward PA, Jenkins D, Lynn PA, Humphrey PP, Blackshaw LA. Excitation of rat colonic afferent fibres by 5-HT(3) receptors. J Physiol. 2002; 544:861-9. [PubMed: 12411529]

23. Mazzia C, Hicks GA, Clerc N. Neuronal location of 5-hydroxytryptamine3 receptor-like immunoreactivity in the rat colon. Neuroscience. 2003; 116:1033-41. [PubMed: 12617944]

24. Furness JB, Jones C, Nurgali K, Clerc N. Intrinsic primary afferent neurons and nerve circuits within the intestine. Prog Neurobiol. 2004; 72:143-64. [PubMed: 15063530]

25. Blackshaw LA, Grundy D. Effects of 5-hydroxytryptamine on discharge of vagal mucosal afferent fibres from the upper gastrointestinal tract of the ferret. J Auton Nerv Syst. 1993; 45:41-50. [PubMed: 8227963]

26. Zhu JX, Zhu XY, Owyang C, Li Y. Intestinal serotonin acts as a paracrine substance to mediate vagal signal transmission evoked by luminal factors in the rat. J Physiol. 2001; 530:431-42. [PubMed: 11158274]

27. Fukumoto S, Tatewaki M, Yamada T, Fujimiya M, Mantyh C, Voss M, Eubanks S, Harris M, Pappas TN, Takahashi T. Short-chain fatty acids stimulate colonic transit via intraluminal 5-HT release in rats. Am J Physiol Regul Integr Comp Physiol. 2003; 284:R1269-76. [PubMed: 12676748]

28. Nakade Y, Fukuda H, Iwa M, Tsukamoto K, Yanagi H, Yamamura T, Mantyh C, Pappas TN, Takahashi T. Restraint stress stimulates colonic motility via central corticotropin-releasing factor and peripheral 5-HT3 receptors in conscious rats. Am J Physiol Gastrointest Liver Physiol. 2007; 292:G1037-44. [PubMed: 17158256]

29. Wener J, Morton HS, Polonsky A. The effects of vagotomy on colonic function; observations through a transverse colostomy in a patient with ulcerative colitis. Gastroenterology. 1952; 22:250-6. [PubMed: 12980247]

30. Takahashi T, Owyang C. Characterization of vagal pathways mediating gastric accommodation reflex in rats. J Physiol (Lond). 1997; 504:479-88. [PubMed: 9365919]

31. Ridolfi TJ, Tong WD, Takahashi T, Kosinski L, Ludwig KA. Sympathetic and Parasympathetic Regulation of Rectal Motility in Rats. J Gastrointest Surg. 2009

32. Taniguchi H, Ariga H, Zheng J, Ludwig K, Mantyh C, Pappas TN, Takahashi T. Endogenous ghrelin and 5-HT regulate interdigestive gastrointestinal contractions in conscious rats. Am J Physiol Gastrointest Liver Physiol. 2008; 295:G403-11. [PubMed: 18566321]

33. Babygirija R, Zheng J, Ludwig K, Takahashi T. Central oxytocin is involved in restoring impaired gastric motility following chronic repeated stress in mice. Am J Physiol Regul Integr Comp Physiol. 298:R157-65. [PubMed: 19889866]

34. Zheng J, Dobner A, Babygirija R, Ludwig K, Takahashi T. Effects of repeated restraint stress on gastric motility in rats. Am J Physiol Regul Integr Comp Physiol. 2009; 296:R1358-65. [PubMed: 19261914]

35. Yang N, Tian YM, Zhang XH, Zheng LF, Xue H, Chen X, Zhu L, Zhu JX. A dual role of 5hydroxytryptamine receptor 3 in serotonin induced ion transport in rat distal colon. Eur $\mathbf{J}$ Pharmacol. 2008; 584:137-43. [PubMed: 18313044]

36. Fukuda H, Tsuchida D, Koda K, Miyazaki M, Pappas TN, Takahashi T. Inhibition of sympathetic pathways restores postoperative ileus in the upper and lower gastrointestinal tract. J Gastroenterol Hepatol. 2007; 22:1293-9. [PubMed: 17688668] 
37. Taniyama K, Makimoto N, Furuichi A, Sakurai-Yamashita Y, Nagase Y, Kaibara M, Kanematsu T. Functions of peripheral 5-hydroxytryptamine receptors, especially 5-hydroxytryptamine 4 receptor, in gastrointestinal motility. J Gastroenterol. 2000; 35:575-82. [PubMed: 10955595]

38. Varma JS. Autonomic influences on colorectal motility and pelvic surgery. World J Surg. 1992; 16:811-9. [PubMed: 1462613]

39. Taylor T, Smith AN, Fulton M. Effects of hysterectomy on bowel and bladder function. Int J Colorectal Dis. 1990; 5:228-31. [PubMed: 2286807]

40. Menardo G, Bausano G, Corazziari E, Fazio A, Marangi A, Genta V, Marenco G. Large-bowel transit in paraplegic patients. Dis Colon Rectum. 1987; 30:924-8. [PubMed: 3691262]

41. van Duijvendijk P, Slors JF, Taat CW, van Tets WF, van Tienhoven G, Obertop H, Boeckxstaens GE. Prospective evaluation of anorectal function after total mesorectal excision for rectal carcinoma with or without preoperative radiotherapy. Am J Gastroenterol. 2002; 97:2282-9. [PubMed: 12358246]

42. Lazorthes F, Chiotasso P, Gamagami RA, Istvan G, Chevreau P. Late clinical outcome in a randomized prospective comparison of colonic $\mathrm{J}$ pouch and straight coloanal anastomosis. $\mathrm{Br} \mathrm{J}$ Surg. 1997; 84:1449-51. [PubMed: 9361611]

43. Beattie DT, Smith JA. Serotonin pharmacology in the gastrointestinal tract: a review. Naunyn Schmiedebergs Arch Pharmacol. 2008; 377:181-203. [PubMed: 18398601]

44. Baker DE. Rationale for using serotonergic agents to treat irritable bowel syndrome. Am J Health Syst Pharm. 2005; 62:700-11. quiz 712-3. [PubMed: 15790796]

45. Gershon MD. Review article: serotonin receptors and transporters -- roles in normal and abnormal gastrointestinal motility. Aliment Pharmacol Ther. 2004; 20(Suppl 7):3-14. [PubMed: 15521849]

46. Gershon MD, Tack J. The serotonin signaling system: from basic understanding to drug development for functional GI disorders. Gastroenterology. 2007; 132:397-414. [PubMed: 17241888]

47. Gershon MD, Drakontides AB, Ross LL. Serotonin: Synthesis and Release from the Myenteric Plexus of the Mouse Intestine. Science. 1965; 149:197-9. [PubMed: 14305120]

48. Sikander A, Rana SV, Prasad KK. Role of serotonin in gastrointestinal motility and irritable bowel syndrome. Clin Chim Acta. 2009; 403:47-55. [PubMed: 19361459]

49. Gershon MD. 5-HT (serotonin) physiology and related drugs. Curr Opin Gastroenterol. 2000; 16:113-20. [PubMed: 17024028]

50. Poole DP, Xu B, Koh SL, Hunne B, Coupar IM, Irving HR, Shinjo K, Furness JB. Identification of neurons that express 5-hydroxytryptamine4 receptors in intestine. Cell Tissue Res. 2006; 325:41322. [PubMed: 16628410]

51. Kim HS. 5-Hydroxytryptamine4 receptor agonists and colonic motility. J Smooth Muscle Res. 2009; 45:25-9. [PubMed: 19377270]

52. Kojima Y, Nakagawa T, Katsui R, Fujii H, Nakajima Y, Takaki M. A 5-HT4 agonist, mosapride, enhances intrinsic rectorectal and rectoanal reflexes after removal of extrinsic nerves in guinea pigs. Am J Physiol Gastrointest Liver Physiol. 2005; 289:G351-60. [PubMed: 15817810]

53. Costedio MM, Hyman N, Mawe GM. Serotonin and its role in colonic function and in gastrointestinal disorders. Dis Colon Rectum. 2007; 50:376-88. [PubMed: 17195902] 


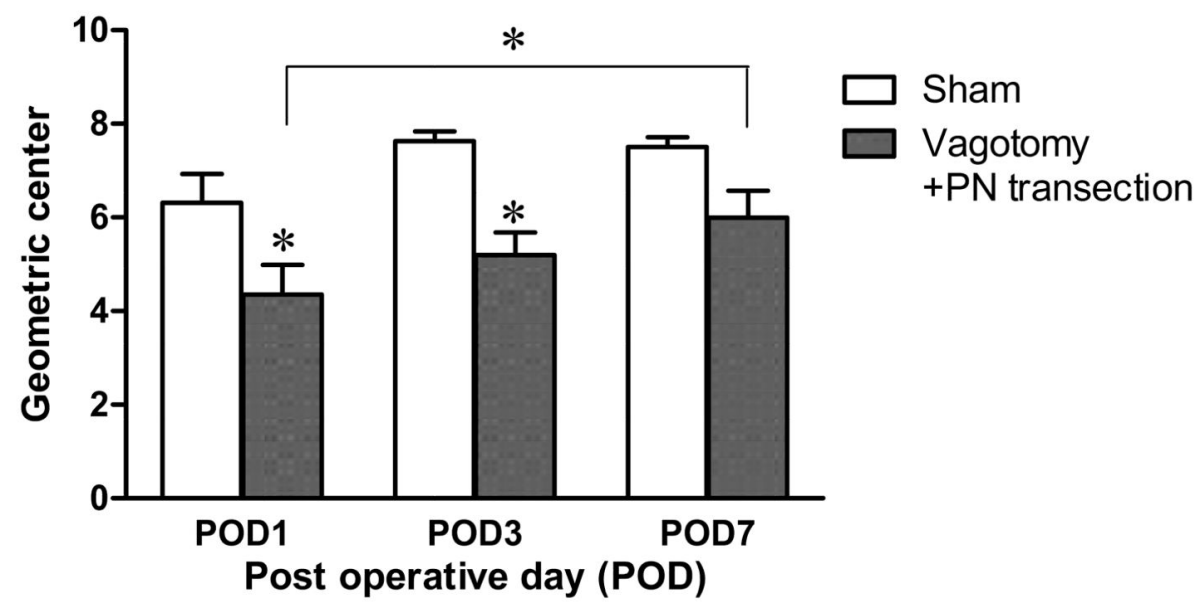

Fig. 1.

Effect of the parasympathetic denervation (vagotomy plus pelvic nerve (PN) transection) on colonic transit. The geometric center (GC), measured with the distribution of ${ }^{51} \mathrm{Cr}$, significantly decreased at POD 1 and POD 3, compared to sham group. The delayed colonic transit was restored at POD 7 (Two-way ANOVA, n=6-8, * $\mathrm{p}<0.05$ ). 


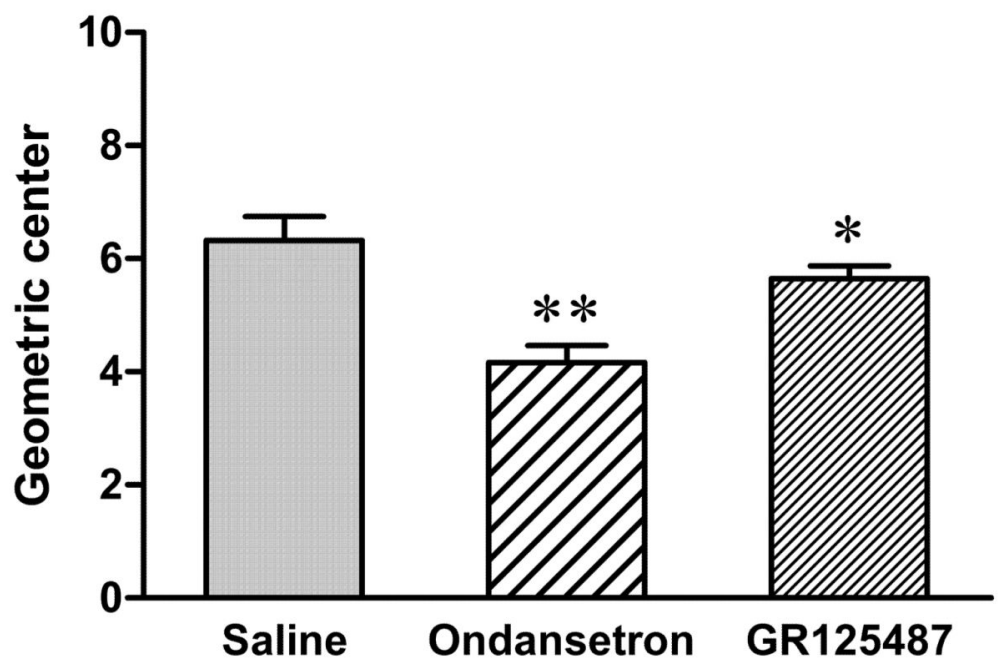

Fig. 2.

Effects of 5- $\mathrm{HT}_{3}$ and 5- $\mathrm{HT}_{4}$ receptors antagonist on colonic transit after the parasympathetic denervation. At POD 7 after parasympathetic denervation, the restored colonic transit was significantly antagonized by the administration of ondansetron $(1 \mathrm{mg} / \mathrm{kg}, \mathrm{sc})$ when compared to that of the saline-injected animals. GR125,487 also significantly attenuated colonic transit, compared to the saline-injected animals (One-way ANOVA, *p<0.05, $* * \mathrm{p}<0.01, \mathrm{n}=6)$. 
A

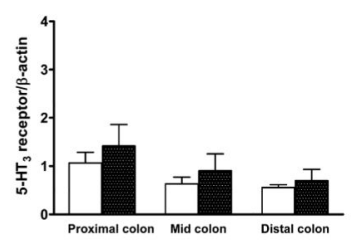

B

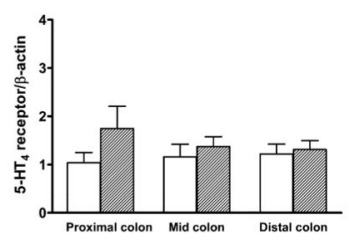

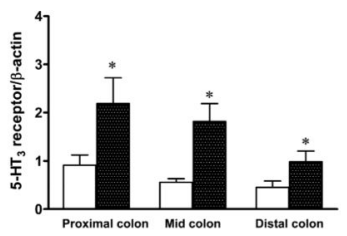

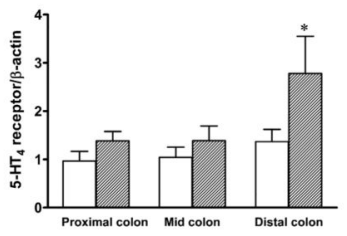

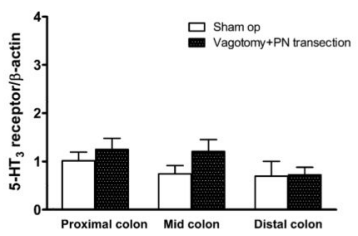

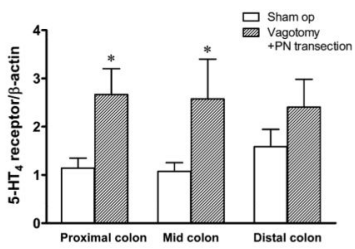

Fig. 3.

Relative expression of 5- $\mathrm{HT}_{3}$ receptor (A) and 5- $\mathrm{HT}_{4}$ receptor (B) mRNA within the mucosal/submucosal layer of the colon after the parasympathetic denervation [vagotomy plus pelvic nerve $(\mathrm{PN})$ transection]. $5-\mathrm{HT}_{3}$ receptor mRNA expression was significantly increased at the proximal, mid and distal colon at POD 3 (A). 5- $\mathrm{HT}_{4}$ receptor mRNA expression was significant increased only in the distal colon at POD 3, while 5- $\mathrm{HT}_{4}$ receptor mRNA expression was significantly increased at the mid and distal colon at POD 7 (B) (Two-way ANOVA, * $\mathrm{p}<0.05$ compared to sham group, $\mathrm{n}=6$ ). 
A

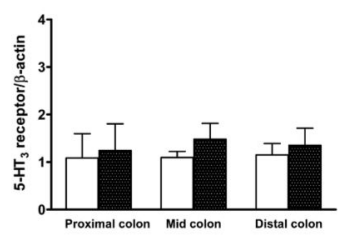

B

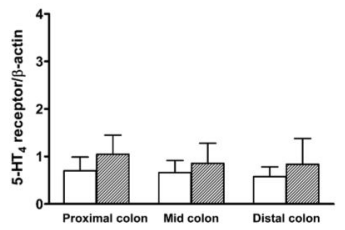

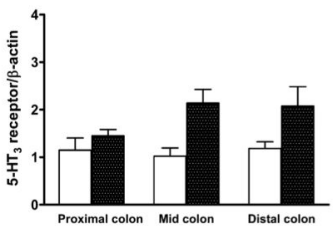
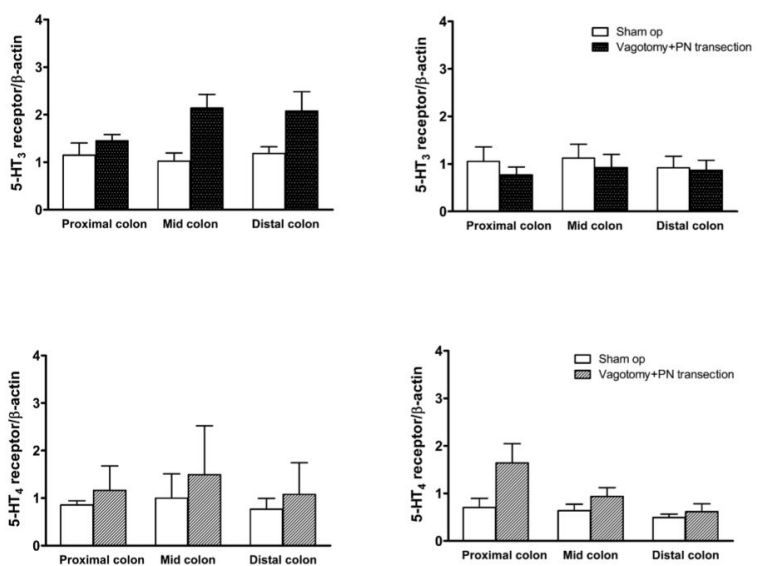

Fig. 4.

Relative expression level of $5-\mathrm{HT}_{3}$ receptor $(\mathrm{A})$ and $5-\mathrm{HT}_{4}$ receptor $(\mathrm{B}) \mathrm{mRNA}$ within the LMMP of the colon after the parasympathetic denervation [vagotomy plus pelvic nerve (PN) transection]. At POD 1, 3 and 7, there were no significant changes observed in mRNA expression of 5- $\mathrm{HT}_{3}$ and $5-\mathrm{HT}_{4}$ receptors of the entire colon, compared to sham groups. 